\title{
Mycoplasmas Isolated from the Respiratory Tract of Cattle and Goats in Tanzania
}

\author{
By L.J.M. Kusiluka ${ }^{l, 3}$, B. Ojeniyi ${ }^{l}$, N.F. Friis ${ }^{2}$, R.R. Kazwala ${ }^{3}$ and B. Kokotovic ${ }^{2}$
}

${ }^{1}$ Department of Veterinary Microbiology, The Royal Veterinary and Agricultural University, ${ }^{2}$ Danish Veterinary Laboratory, Denmark, and ${ }^{3}$ Department of Veterinary Medicine and Public Health, Sokoine University of Agriculture, Morogoro, Tanzania.

\begin{abstract}
Kusiluka LJM, Ojeniyi B, Friis NF, Kazwala RR, Kokotovic B: Mycoplasmas isolated from the respiratory tract of cattle and goats in Tanzania. Acta vet. scand. 2000, 41, 299-309. - A microbiological study of the mycoplasma flora in the respiratory tracts of cattle and goats in selected regions of Tanzania is described. In the examination of cattle, mycoplasmas were isolated from $60(17.8 \%)$ of the 338 examined lung samples, $8(47.1 \%)$ of the 17 lymph nodes, 4 (13.3\%) of the 30 pleural fluid samples and 4 (3.9\%) of the 103 nasal swabs examined. All the isolates were identified as Mycoplasma mycoides subsp. mycoides, Small Colony type except for one isolate from pleural fluid which was identified as Mycoplasma arginini. M. mycoides subsp. mycoides, Small Colony type was isolated from samples originating from Dodoma, Iringa, Mbeya, Morogoro and Shinyanga regions where outbreaks of contagious bovine pleuropneumonia had been reported. In the examination of goats, mycoplasmas were isolated from 54 $(34.0 \%)$ of the 159 examined lung samples, $41(18.1 \%)$ of the 226 nasal swabs and 4 $(40.0 \%)$ of the 10 pleural fluid samples. The species demonstrated were Mycoplasma capricolum subsp. capripneumoniae, M. mycoides subsp. mycoides, Small Colony type Mycoplasma ovipneumoniae and M.Capricolum subsp. arginini. The isolation of M. capripneumoniae in the Coast and Morogoro regions confirmed the presence of contagious caprine pleuropneumonia in the regions.
\end{abstract}

\section{pleuropneumonia.}

\section{Introduction}

Mycoplasmas are associated with a variety of disease syndromes in livestock including pneumonia, mastitis, polyarthritis, polyserositis, keratoconjunctivitis and reproductive disorders (Stalheim 1990). Contagious bovine pleuropneumonia (CBPP) caused by Mycoplasma mycoides subsp. mycoides, Small Colony (SC) type (M. mycoides $\mathrm{SC}$ ) is the most serious respiratory mycoplasmosis of cattle in Africa, Asia, Middle East and south-western Europe (Provost et al. 1987). Besides M. mycoides SC several other pathogenic species exist in cattle such as $M$. bovis which causes mastitis, pneumonia, arthritis and reproductive disorders (-
Pfützner \& Sachse 1996). M. dispar, Ureaplasma diversum and $M$. bovigenitalium are also involved in the calf pneumonia complex (Thomas et al. 1982, Ross 1993). M. bovigenitalium, M. canadense, M. alkalescens and $M$. californicum cause mastitis (Ross 1993) and $M$. bovigenitalium and $U$. diversum are also involved in bovine genital and reproductive diseases (Ernø 1974). M. bovoculi is associated with infectious bovine keratoconjunctivitis (Friis \& Pedersen 1979).

Contagious caprine pleuropneumonia (CCPP) caused by $M$. capricolum subsp. capripneumoniae (M. capripneumoniae) is one of the 
most contagious and highly fatal mycoplasma diseases of goats. The disease is prevalent in Africa, the Mediterranean and Asia (Bölske 1995, Thiaucourt \& Bölske 1996). M. mycoides subsp. mycoides, large colony (LC) type ( $M$. mycoides LC) and M. mycoides subsp. capri (M. capri) cause pleuropneumonia which may be indistinguishable from CCPP (Lefèvre et al. 1987, Jones 1989) and, together with M. capricolum subsp. capricolum (M. capricolum), $M$. agalactiae and $M$. putrefaciens are involved in the mastitis, arthritis, keratitis, pneumonia and septicaemia (MAKePS) syndrome in goats (Thiaucourt \& Bölske 1996). M. conjunctivae causes caprine and ovine keratoconjunctivitis while $M$. ovipneumoniae is associated with pneumonia in small ruminants (DaMassa et al. 1992). M. arginini is frequently isolated from lungs of goats but its role in respiratory disease is unclear (Jones 1989).

M. mycoides SC, M. mycoides LC, M. capri, $M$. capricolum, M. capripneumoniae and Mycoplasma sp. bovine group 7 have been grouped together under the so-called 'Mycoplasma mycoides cluster' because of their biochemical, antigenic and phylogenetic similarities (Bölske 1995). They cause diseases that have a global socio-economic impact (Rweyemamu \& Benkirane 1996). M. putrefaciens is closely related to the M. mycoides cluster (Weisburg et al. 1989). CBPP has been endemic in north-eastern Uganda and northern Kenya for many years and cattle movements in the 1990 s spread the disease to the southern parts of these countries, Rwanda and Zaire (Rweyemamu \& Benkirane 1996). CBPP was eradicated from Tanzania in 1964 (Lwebandiza 1969) but it was reintroduced into the north-eastern part of the country from Kenya in 1990 (Bölske et al. 1995) and into north-western Tanzania from southern Uganda in 1991 (Rweyemamu \& Benkirane 1996). Since then, CBPP has spread to many parts of the country and presently, it is the most devastating disease of cattle threatening more than 9.5 million heads of cattle in 17 regions of the country (Melewas 1999).

CCPP was confirmed by isolation of $M$. capripneumoniae (formerly Mycoplasma strain F38) in Kenya in 1976, and since then it has remained endemic in the country (MacOwan \& Minette 1976, Rurangirwa et al. 1991). In Uganda, CCPP was confirmed in 1993 (Bölske et al. 1994). The disease has been suspected to be present in Tanzania since the early 1980s (Nyange \& Mbise 1983, Msami 1991) but it was only confirmed by isolation of $M$. capripneumoniae in 1998 (Msami et al. 1998a). Like CBPP, CCPP is rapidly spreading; now encompassing the major goat-rearing regions of the country (Dr. Ponela-Mlelwa, personal communication). Limited studies have been conducted concerning CBPP, CCPP and other respiratory mycoplasmoses of cattle and goats in Tanzania. Therefore, this study was designed to elucidate the mycoplasma flora in the respiratory tracts of cattle and goats in selected regions of the country with special emphasis on the M. mycoides cluster.

\section{Materials and methods}

Source of samples

This study was carried out in Tanzania from October 1998 to November 1999. It was based on examination of the respiratory tract specimens (lungs, lymph nodes, pleural fluid, fibrin and nasal swabs) from cattle and goats from 11 different regions of the country, namely: Arusha, Dodoma, Dar es Salaam, Iringa, Kagera, Mbeya, Morogoro, Mtwara, Coast, Shinyanga and Tanga. Except for the Coast region, outbreaks of CBPP have been reported in the regions, but data on laboratory confirmation of the disease was scanty. CCPP had only been confirmed in Arusha, Dar es Salaam Kilimanjaro and Tanga regions. Samples from the lower respiratory tract were obtained from slaughter- 
Table 1. Mycoplasmas isolated from specimens of the respiratory tract of cattle in Tanzania.

\begin{tabular}{lcccccccc}
\hline \multicolumn{10}{c}{ Number (\%) infected } \\
\hline & \multicolumn{1}{c}{$\begin{array}{c}\text { Lung } \\
\text { lesions }\end{array}$} & $\begin{array}{c}\text { Lymph } \\
\text { nodes }\end{array}$ & $\begin{array}{c}\text { Pleural } \\
\text { fluid }\end{array}$ & Fibrin & & \multicolumn{2}{c}{$\begin{array}{c}\text { Clinical } \\
\text { respiratory distress }\end{array}$} \\
\hline Mycoplasma spp. & $\begin{array}{c}\text { CBPP } \\
\text { like }\end{array}$ & $\begin{array}{c}\text { Other } \\
\text { types }\end{array}$ & $\begin{array}{c}\text { No } \\
\text { lesions }\end{array}$ & & & & Present & Absent \\
\hline M. mycoides SC & $60(49.6)$ & - & - & $8(47.1)$ & $3(10.0)$ & $2(66.7)$ & $4(11.1)$ & - \\
M. arginini & - & - & - & - & $1(3.3)$ & - & - & - \\
Total no. (\%) infected & $60(49.6)$ & - & - & $8(47.1)$ & $4(13.3)$ & $2(66.7)$ & $4(11.1)$ & - \\
Total no. examined & 121 & 133 & 84 & 17 & 30 & 3 & 36 & 67 \\
\hline
\end{tabular}

Figures for samples with no microbial growth and those which showed bacterial or fungal growth are not indicated in the table.

houses and some of them were collected from animals which died naturally from disease or had been sacrificed. Lungs without pneumonic lesions were also examined for comparison. After collection, the specimens were kept in a cool box during transport to the laboratory at Sokoine University of Agriculture, Morogoro or stored at $-20^{\circ} \mathrm{C}$ until transported to the laboratory. Some specimens submitted to the Animal Disease Research Institute (ADRI), Dar es Salaam as part of the National CBPP/CCPP Surveillance Programme and whose records of origin were available were also included in the study. Similarly, samples submitted to the Faculty of Veterinary Medicine, Sokoine University of Agriculture for routine diagnostic work were screened. Depending on their gross pathological appearance, lungs were categorised as CBPP/CCPP like lesions, other types of pneumonias and non-pneumonic cases.

Nasal swabs were collected from cattle and goat herds and some of them were collected at local animal markets. Animals from which nasal swabs were collected were categorised as suffering from respiratory tract disease when they showed nasal discharge and/or distressed respiration and as normal when they did not show these signs. Immediately after collection the swabs were immersed in mycoplasma transport medium and kept in a cool box during transport to the laboratory or stored at $-20^{\circ} \mathrm{C}$ if transport to the laboratory was delayed.

In cattle, a total of 338 lungs comprising 121 with CBPP like lesions, 133 with other pneumonic lesions and 84 without pneumonic lesions were examined (Table 1). Of the lungs with CBPP like lesions, 18 had sequestra. Seventeen lymph nodes comprising 11 mediastinal and 6 bronchial were examined, as were 30 and 3 samples of pleural fluid and fibrin, respectively. A total of 103 nasal swabs comprising 36 and 67 from animals with and without clinical respiratory distress, respectively, were also screened for mycoplasmas.

In goats, 159 lungs were examined, 98 of which had CCPP like lesions (including one with a sequestrum), 47 other pneumonic lesions and 14 were non-pneumonic cases (Table 2). Ten pleural fluid samples comprising 6 from cases with CCPP like lesions and 4 from cases with other types of pneumonic lesions were screened for mycoplasmas. In addition, a total of 226 nasal swabs comprising 108 collected from animals with clinical respiratory distress and 118 from animals exhibiting no clinical respiratory distress were examined. 
Table 2. Mycoplasmas isolated from specimens of the respiratory tract of goats in Tanzania.

\begin{tabular}{lcccccc}
\hline & \multicolumn{3}{c}{ Number (\%) infected } & & \multicolumn{2}{c}{ Nasal swabs } \\
\cline { 3 - 7 } & & $\begin{array}{c}\text { Lung } \\
\text { lesions }\end{array}$ & & $\begin{array}{c}\text { Pleural } \\
\text { fluid }\end{array}$ & & $\begin{array}{c}\text { Clinical } \\
\text { respiratory distress }\end{array}$ \\
\hline Mycoplasma spp. & CCPP & $\begin{array}{c}\text { Other } \\
\text { types }\end{array}$ & $\begin{array}{c}\text { No } \\
\text { lesions }\end{array}$ & & Present & Absent \\
\hline M. capripneumoniae & $10(10.2)$ & - & - & $1(10.0)$ & - & - \\
M. mycoides subsp. mycoides & $5(5.1)$ & - & - & $1(10.0)$ & $1(0.9)$ & - \\
M. ovipneumoniae & $30(30.6)$ & $3(6.4)$ & - & $1(10.0)$ & $21(19.4)$ & $18(15.3)$ \\
M. arginini & $5(5.1)$ & $1(2.1)$ & - & $1(10.0)$ & $1(0.9)$ & - \\
Total no. (\%) infected & $50(51.0)$ & $4(8.5)$ & - & $4(40.0)$ & $23(21.3)$ & $18(15.3)$ \\
Total no. examined & 98 & 47 & 14 & 10 & 108 & 118 \\
\hline
\end{tabular}

Figures for samples with no microbial growth and those which showed bacterial or fungal growth are not indicated in the table.

\section{Isolation media}

Three types of media selected on the basis of growth requirements of known bovine and caprine mycoplasmas were used for isolation purposes. A modified Hayflick's medium containing $15 \%$ horse- and swine serum, and enriched with arginine and urea, herein abbreviated as HAU, was used for isolation of glucose-, arginine- and urea-metabolising mycoplasmas (Friis 1975). A medium designated as NHS-20, originally developed for isolation of $M$. hyopneumoniae and containing $20 \%$ horse- and swine serum was used mainly for isolation of M. dispar (Kobisch \& Friis 1996). Another Hayflick-based medium, containing 25\% horse- and swine serum and enriched with sodium pyruvate, herein abbreviated as $\mathrm{H} 25 \mathrm{P}$, was used for isolation of $M$. capripneumoniae from CCPP-suspected samples (Bölske et al. 1996). For primary propagation, all media were supplemented with D-cycloserine (Fluka Biochemika, Buchs) in addition to bacitracin and methicillin in NHS-20 and ampicillin in HAU and H25P. Differentiation between arginineand urea-positive cultures was achieved by subculturing in a modified Hayflick's medium en- riched with arginine but no urea, and additionally a NHS-20 medium enriched with urea, $\mathrm{MgSO}_{4}$ and lincomycin (Fluka Biochemika, Buchs). The solid medium was prepared from final liquid medium by adding autoclaved agar, L28 (Oxoid, Hampshire, England) to $0.8 \%$ $0.9 \%$.

\section{Cultural procedures}

Ten-fold serial dilutions to $10^{-6}$ of homogenised lung and lymph node tissue suspensions, pleural fluid and nasal swabs were prepared in all 3 liquid standard media and incubated at $37{ }^{\circ} \mathrm{C}$. Broth cultures were examined daily for colour change of phenol red for 2 weeks. Appearance of slight floccular material and weak turbidity in the broth medium were also used as indicators of growth. Positive cultures were subcultured onto solid medium for the examination of colony morphology. Cultures without evidence of growth after 4 days of incubation were also plated in an attempt to isolate mycoplasmas which do not produce noticeable colour change in broth. The plates were incubated at $37^{\circ} \mathrm{C}$ in a humidified atmosphere with a candle source of $\mathrm{CO}_{2}$. They were examined for mycoplasma 
colonies every second day and discarded if negative after 14 days of incubation.

\section{Identification of isolates}

Isolates of mycoplasmas were cloned by the single colony technique (Stalheim 1990) prior to biochemical characterisation. Biochemical tests including sodium polyanethol sulphonate and digitonin sensitivity, glucose, arginine and urea metabolism, and film and spots production were used for preliminary characterisation (Ernø 1974, Friis 1975, Stalheim 1990). Isolates of the classical mycoplasma types were then identified by the disc growth inhibition test using rabbit hyperimmune sera against the type strains for known bovine and caprine mycoplasmas as previously described (Working Group of the FAO/WHO Programme on Comparative Mycoplasmology 1976). Epi-immunofluorescence on colonies was used as a supplementary test for some isolates for confirmation of the disc growth inhibition test results (Gardella et al. 1983). Isolates showing strong positive reactions in the disc growth inhibition test with PG1 and Y-Goat antisera were further examined for their ability to digest casein and to survive at $+45^{\circ} \mathrm{C}$, in attempt to separate the small (SC) and large (LC) variants of the Mycoplasma mycoides subspecies mycoides (Cottew \& Yeats 1978). The M. mycoides subsp. mycoides isolates from goats and some from cattle were also sent to Dr. Göran Bölske, National Veterinary Institute, Uppsala for further examination by the serum digestion test and molecular methods.

\section{Results}

\section{Disc growth inhibition test}

In the disc growth inhibition test of the M. mycoides cluster, weak interspecies cross-reactions were noted. The cross-reactions were notably strong between the SC- and LC variants of $M$. mycoides subsp. mycoides, rendering them inseparable by this test. The 2 variants were tentatively distinguished by their colony size, sensitivity to $+45^{\circ} \mathrm{C}$, ability to digest casein and liquefy inspissated serum. The type strains PG1 (M. mycoides SC) and Y-Goat (M. mycoides LC) showed unequivocal results which conformed with published literature (Ernø 1983). However, variable results were obtained with the field strains rendering it difficult to assign them to their respective biotypes. However, because typical CBPP lesions are caused only by the SC variants of $M$. mycoides subsp. mycoides, the isolates from cattle with CBPP lesions were considered to be of the SC type. The M. mycoides subsp. mycoides isolates from goats were confirmed to be of the SC type by molecular methods.

\section{Mycoplasmas of cattle}

The prevalence and species of mycoplasmas isolated from cattle in Tanzania are presented in Table 1. Mycoplasmas were demonstrated in 60 $(17.8 \%)$ of the 338 lungs examined, all of which had CBPP like lesions, including 7 sequestra. Of the 17 lymph nodes screened, 8 (47.1\%) of them, comprising 5 mediastinal and 3 bronchial nodes were mycoplasma-positive. Mycoplasmas were also isolated in $4(13.3 \%)$ of the 30 pleural fluid samples, $4(3.9 \%)$ of the 103 nasal swabs and 2 fibrin samples. Bacterial and fungi were encountered in some of the specimens while others did not show any microbial growth.

M. mycoides SC was isolated from the lungs, lymph nodes, pleural fluid and fibrin samples, all originating from cases with typical CBPP pathology (Table 1). The 4 mycoplasma-positive nasal swabs also yielded $M$. mycoides SC and they were among 11 swabs collected from animals in a herd in which CBPP was confirmed by isolation of $M$. mycoides $\mathrm{SC}$ from the lung and pleural fluid of a sacrificed animal. $M$. arginini was identified in only 1 sample of pleu- 
ral fluid. Mixed $M$. mycoides $\mathrm{SC}$ and bacterial flora were detected in $31(51.7 \%)$ of the $60 \mathrm{my}$ coplasma-positive lungs. Bacterial growth was also demonstrated in $7(87.5 \%)$ of the 8 mycoplasma-positive lymph nodes, and in 1 nasal swab and 1 fibrin sample.

M. mycoides $\mathrm{SC}$ was isolated from specimens originating from Dodoma, Iringa, Mbeya, Morogoro and Shinyanga regions where outbreaks of CBPP had been reported, but none from specimens originating from Arusha, Dar es Salaam, Kagera, Mtwara and Tanga where the disease had also been reported. The pleural fluid sample that yielded $M$. arginini originated from Kagera region.

\section{Mycoplasmas of goats}

The prevalence and species of mycoplasmas isolated from goats in Tanzania are presented in Table 2. Mycoplasmas were isolated in 54 (34.0\%) of the 159 lung specimens, 41 (18.1\%) of the 226 nasal swabs and $4(40 \%)$ of the 10 pleural fluid samples. Some specimens appeared to be sterile while others revealed bacterial and fungal growth.

M. capripneumoniae was identified in 10 (18.5\%) of the 54 mycoplasma-positive lungs, all of them with typical CCPP lesions, while $M$. mycoides SC was identified in $5(9.3 \%)$ of the 54 infected lungs, all with CCPP like lesions (one of the lungs contained a sequestrum). $M$. ovipneumoniae and $M$. arginini were isolated in $33(61.1 \%)$ and $6(11.1 \%)$ of the infected lungs, respectively. M. capripneumoniae, M. mycoides SC and M. ovipneumoniae were concurrently isolated from one sample of pleural fluid from a goat with CCPP like lesions. M. ovipneumoniae, M. mycoides SC and M. arginini were demonstrated in $39(95.1 \%), 1(2.4 \%)$ and $1(2.4 \%)$ of mycoplasma-infected nasal swabs, respectively. Five ( $9.3 \%$ ) of the 54 infected lungs contained mixed M. capripneumoniae and M. ovipneumoniae infections. Combinations of $M$. mycoides SC and M. arginini, and M. mycoides $\mathrm{SC}$ and $M$. ovipneumoniae were observed in 1 lung each while a mixed infection of $M$. ovipneumoniae and $M$. arginini was recorded in 1 nasal swab. Mixed mycoplasma and bacterial flora were also common.

$M$. capripneumoniae was isolated from goats in the Coast and Morogoro regions while M. mycoides $\mathrm{SC}$ was encountered in specimens originating from the Coast, Dodoma and Morogoro regions. $M$. ovipneumoniae was encountered in samples originating from the Coast, Dar es Salaam, Dodoma, Iringa and Morogoro regions.

\section{Discussion}

This study has demonstrated that mycoplasma infections are prevalent in cattle and goats in the study areas. The predominant mycoplasma in cattle was $M$. mycoides SC, the aetiological agent for CBPP. This indicates that CBPP is still the major respiratory mycoplasmosis of cattle in the country as also reported by others (Bölske et al. 1995, Msami et al. 1998b). It is noteworthy that several bovine mycoplasmas such as $M$. bovis, M. dispar, M. bovirhinis, $M$. bovigenitalium and Ureaplasma spp. were not found although they are common in the respiratory tract of cattle in Europe, America and Asia (Shimizu 1982, Thomas et al. 1982, Ter Laak et al. 1992). This finding indicates that these mycoplasmas have probably not yet been introduced and/or established in the Tanzanian cattle population. Like in other African countries, information on bovine respiratory mycoplasmas in indigenous cattle apart from M. $m y$ coides SC is lacking although they have been demonstrated in imported Bos taurus breeds (Taoudi et al. 1985). Differences in the management systems may also account for this observation because it has been observed that intensification of management favours establishment of mycoplasmas in the respiratory tract (Friis \& Krogh 1983, Tanskanen 1987). 
The Tanzania Zebu cattle examined in this study were from the traditional extensive management system as opposed to the intensive systems in Europe and America.

The isolation of $M$. mycoides SC from the nasal swabs of cattle and goats signifies the role of such animals as carriers for the infection (Lefèvre et al. 1987, Regalla \& Lefèvre 1996), as is the isolation of M. mycoides SC from sequestra (Provost et al. 1987, Masiga \& Domenech 1995). Carrier animals are epidemiologically important because they can disseminate the disease over large areas without being noticed. The isolation of $M$. mycoides SC from a sequestrum in a treated goat has not been reported before. The small number of specimens from Arusha, Dar es Salaam, Kagera, Mtwara and Tanga regions, most of which had no CBPP lesion, was probably the reason for failure to isolate $M$. mycoides SC from these samples.

The isolation of $M$. capripneumoniae from goats in the Coast and Morogoro regions confirms that the 2 regions are also CCPP-affected areas and raises the number of infected regions to 6 after Arusha, Dar es Salaam, Kilimanjaro and Tanga regions in which the disease was confirmed in 1998 (Msami et al. 1998a). A detailed description of the CCPP outbreak is dealt with elsewhere (Kusiluka et al. 2000). It was noteworthy, however, that the isolation rate for $M$. capripneumoniae in lungs with typical CCPP lesions was low despite using the medium specially recommended for the purpose (Bölske et al. 1996). The more fastidious M. capripneumoniae may have been overgrown by the readily growing $M$. ovipneumoniae and bacteria leading to difficulties in its isolation (Thiaucourt et al. 1996). Although bacteria were not characterised during the present work, other workers have demonstrated that some pathogenic bacteria such as Pasteurella spp. are often found together with mycoplamas in pneumonic bovine and caprine lungs (Bitsch et al. 1976,
Jones \& Wood 1988). On the other hand, the low isolation rate may be attributed to the widespread treatment of the CCPP-suspected goats with antibiotics such as tetracycline and tylosin as indicated from field reports.

M. ovipneumoniae was the most prevalent mycoplasma in the lungs and nasal swabs of goats. This is a ubiquitous mycoplasma of small ruminants worldwide (Lefèvre et al. 1987, Jones 1989) and together with $M$. arginini it had been previously isolated from goat lungs in Tanzania (Msami 1991).

Serological cross-reactions among members of the $M$. mycoides cluster in the disc growth inhibition test have been reported (Bölske 1995) and were also observed in this study. The crossreactions were particularly strong between $M$. mycoides subsp. mycoides isolates from typical CBPP lesions in cattle and from cases of pleuropneumonia in goats, rendering it difficult to classify them as SC or LC types. However, because the SC variants occur primarily in cattle where they are associated with typical CBPP lesions (Freundt 1983), isolates from CBPP lesions were considered to be of the SC type. The $\mathrm{SC}$ variants of $M$. mycoides subsp. mycoides have also been isolated from goats with pneumonia and sheep with mastitis (Brandao 1995) but their pathogenicity in these hosts under natural conditions has not been well investigated. However, Machado et al. (1998) induced fibrinous pleuropneumonia in 2 sheep and mastitis in one goat following experimental infection with SC isolates from small ruminants.

$M$. mycoides LC is an established cause of pleuropneumonia and is frequently isolated from goats (Bölske et al. 1989, DaMassa et al. 1992, Rodriguez et al. 1995, Gutierrez et al. 1999). In the present study, the field isolates from goats did not produce convincing results in the casein- and serum digestion tests or survival at $+45^{\circ} \mathrm{C}$ as would be expected of the LC types. Ernø (1983) also did not demonstrate a clear 
proteolytic activity in $\mathrm{SC}$ isolates from goats suggesting that these tests may sometimes fail to separate the 2 biotypes. Thus, definitive identification can only be achieved by molecular biology methods. Noteworthy, goats from which $M$. mycoides SC were isolated grazed in the same pastures with cattle and were housed less than 100 metres from cattle barns, and yet no single CBPP case has been recorded in cattle for more than one year since the outbreak of pleuropneumonia in goats. This probably suggests that the mycoplasmas have not been transmitted to or are not pathogenic for cattle. Despite its limitations, the disc growth inhibition test is the recommended and most widely used conventional method for preliminary identification of mycoplasmas and it is a method easily available in small laboratories which lack facilities for molecular identification of mycoplasmas (Freundt 1974, Subcommitee on the Taxonomy of Mollicutes 1979).

In conclusion, this study has demonstrated that mycoplasmas including members of the $M . m y$ coides cluster are prevalent in the respiratory tracts of cattle and goats in the regions of Tanzania covered under the study. The fact that $M$. mycoides SC was isolated from areas where CBPP had been reported and the absence of other pathogenic mycoplasmas in the bovine respiratory tract indicate that CBPP is the major respiratory mycoplasmosis of cattle in Tanzania as it has been reported in 17 out the 20 regions. The confirmation of CCPP in the Coast and Morogoro regions signifies a serious threat to the goat population in these regions. Therefore, it is suggested that efforts to control CBPP and CCPP in Tanzania should be intensified in order to minimise economic losses within the country and to prevent spread of these diseases to neighbouring countries in southern Africa such as Malawi, Mozambique and Zambia which are probably still free from the diseases. Adoption of a more vigilant disease surveil- lance system, restriction and control of animal movements, well co-ordinated vaccination campaigns and educational programmes for stock owners enabled the eradication of CBPP from Tanzania in 1964. These manoeuvres are still valid today and they can be applied to control and eventually eradicate these diseases from the cattle and goat populations.

\section{Acknowledgements}

The co-operation of veterinary officers, meat inspectors and animal owners in areas from which samples were collected is greatly appreciated. We thank Andrea Cosmas, Maulid Ndaki and Jonas Fitwangile (Sokoine University of Agriculture) and Lotte Clemmensen and Ulla Amtoft (Danish Veterinary Laboratory) for their excellent technical assistance. We also thank Dr. Göran Bölske of the National Veterinary Institute, Uppsala for confirming the identity of the some mycoplasma isolates. The Danish International Development Agency is thanked for the Ph.D. grant to the first author.

\section{References}

Bitsch V, Friis NF, Krogh HV: A microbiological study of pneumonic calf lungs. Acta vet. scand. $1976,17,32-42$.

Brandao E: Isolation and identification of Mycoplasma mycoides subspecies mycoides SC strains in sheep and goats. Vet. Rec. 1995, 136, 98-99.

Bölske $G$ : Respiratory mycoplasmoses in goats especially with regard to diagnosis of contagious caprine pleuropneumonia. Ph.D. thesis, Swedish University of Agricultural Sciences, Uppsala, 1995.

Bölske G, Engvall A, Renström LHM, Wierup M: Experimental infections in goats with Mycoplasma mycoides subspecies mycoides, LC type. Res. Vet. Sci. 1989, 46, 247-252.

Bölske G, Wilhelmsson E, Twinamasiko E, Johansson $K E$ : Detection of Mycoplasma capricolum subsp. capripneumoniae in goats and sheep in Uganda. IOM Lett. 1994, 2, 19-20.

Bölske, G, Mattson JG, Basunana CR, Bergstrom K, Wesonga $H$, Johansson, KE: Diagnosis of contagious caprine pleuropneumonia by detection and identification of Mycoplasma capricolum subsp. capripneumoniae by PCR and restriction enzyme analysis. J. Clin. Microbiol. 1996, 34, 785-791. 
Bölske G, Msami HM, Gunnarsson A, Kapaga AM, Loomu PM: Contagious bovine pleuropneumonia in northern Tanzania, culture confirmation and serological studies. Trop. Anim. Hlth. Prod. 1995, 27, 193-201.

Cottew GS, Yeats FR: Subdivision of Mycoplasma mycoides subsp. mycoides from cattle and goats into two types. Aust. Vet. J. 1978, 54, 293-296.

DaMassa AJ, Wakenell PS, Brooks DL: Mycoplasmas of goats and sheep. J. Vet. Diagn. Invest. 1992, 4, 101-113.

Ernø H: Bovine Mycoplasmas: Cultural, biochemical, immunological and pathogenicity studies. DVSc thesis. University of Aarhus, 1974.

Ernø H: Mycoplasmas related to Mycoplasma mycoides subsp. mycoides. In: Hall SA (ed): The diagnosis of contagious bovine pleuropneumonia and other infections with Mycoplasma mycoides subspecies mycoides. A Seminar in the CEC Programme of Coordination of Research on Animal Pathology held in Brussels, June 16-17, 1983. Document No. EUR 8654. Commission of the European Communities, Luxembourg, 1983.

Freundt EA: Mycoplasmas. Practical aspects of serological identification. Les Colloques de l'Institut National de la Santé et de la Recherche Médicale. 1974, 33, 161-168.

Freundt EA: Historical and taxonomic position of the agent and the role of reference centres. In: Hall SA (ed): The diagnosis of contagious bovine pleuropneumonia and other infections with $M y$ coplasma mycoides subspecies mycoides. A Seminar in the CEC Programme of Coordination of Research on Animal Pathology held in Brussels, June 16-17, 1983. Document No. EUR 8654. Commission of the European Communities, Luxembourg, 1983.

Friis NF: The SPS and digitonin tests applied to porcine mycoplasmas. Acta vet. scand. 1975, 16, 474-476.

Friis $N F$, Krogh $H V$ : Isolation of mycoplasma from Danish cattle. Nord Vet. Med. 1983, 35, 74-81.

Friis NF, Pedersen KB: Isolation of Mycoplasma bovoculi from cases of infectious bovine keratoconjunctivitis. Acta vet. scand. 1979, 20, 51-59.

Gardella RS, DelGiudice RA, Tully JG: Immunofluorescence. In: Razin S, Tully JG (eds), Methods in Mycoplasmology. Vol. I. Mycoplasma characterization. Academic Press, New York, 1983.

Gutierrez C, Rodriguez JL, Montoya JA, Fenandez A: Clinico-pthological and haematological findings in goat kids experimentally infected simultane- ously with Mycoplasma mycoides subsp. capri and Mycoplasma mycoides subsp. mycoides (large colony-type). Small Rum. Res. 1999, 31, 187-192.

Jones GE: Contagious Caprine Pleuropneumonia. Technical Series No. 9. Office International Des Epizooties, Paris, 1989.

Jones GE, Woods AR: Microbiological and serological studies on caprine pneumonias in Oman. Res. Vet. Sci. 1988, 44, 125-131.

Kobisch M, Friis NF: Swine mycoplasmoses. Rev. sci. tech. Off. int. Epiz. 1996, 15, 1569-1605.

Kusiluka LJM, Semuguruka WD, Kazwala RR, Ojeniyi B, Friis NF: Demonstration of Mycoplasma capricolum subsp. capripneumoniae and Mycoplasma mycoides subsp. mycoides, Small Colony type in outbreaks of caprine pleuropneumonia in eastern Tanzania. Acta vet. scand. 20000, 41, 000-000.

Lefèvre PC, Jones GE, Ojo MO: Pulmonary mycoplasmoses of small ruminants. Rev. sci. tech. Off. int. Epiz. 1987, 6, 759-799.

Lwebandiza TS: Contagious bovine pleuropneumonia in Tanzania. Bull. Off. int. Epiz. 1969, 72, 71 78.

Machado $M$, Ferreira H, Ramos MA, Brandao E, Tavares $A$, Cardoso $M$ : Experimental infection of sheep and goats with Mycoplasma mycoides subsp. mycoides SC isolated from small ruminants. In: Leori G, Santini F, Scanziani E and Frey (eds), Mycoplasmas of ruminants: pathogenicity, diagnostics, epidemiology and molecular genetics. COST 826, Report EUR 18018. European Communities, Luxembourg, 1998.

MacOwan KJ, Minette JE: A mycoplasma from acute contagious caprine pleuropneumonia in Kenya. Trop. Anim. Hlth. Prod. 1976, 8, 91-95.

Masiga WN, Domenech J: Overview and epidemiology of contagious bovine pleuropneumonia in Africa. Rev. sci. tech. Off. int. Epiz. 1995, 14, 611-620.

Melewas JN: The history, spread and extent of CBPP and CCPP in Tanzania - The National Perspectives. Paper presented at the Sokoine University of Agriculture Workshop on CBPP and CCPP, Morogoro, 27-28 July, 1999.

Msami HM: Pneumonias in goats in Tanzania with special regard to mycoplasma infections. Proc. $9^{\text {th }}$ Tanzania Vet. Assoc. Sci. Conf. Arusha, December 1991.

Msami HM, Kapaga AM, Bölske G, Kimaro RT, Mundogo $J$, Mbise A : Occurance of contagious 
caprine pleuropneumonia in Tanzania. 1998a, 18, 285-297.

Msami HM, Ponela-Mlelwa T, Mtei BJ: Contagious bovine pleuropneumonia in Tanzania: Current status. Paper presented at the ARC-Onderstepoort OIE International Congress with WHOCosponsorship on Anthrax, Brucellosis, CBPP, Clostridial and Mycobacterial diseases, Berg-enDal, Kruger National Park, South Africa, 9-15 August, 1998b.

Nyange JFC, Mbise AN: Suspected contagious caprine pleuropneumonia and canine parvovirus enteritis in Northern Tanzania. Proc. the $1^{\text {st }}$ Tanzania Vet. Assoc. Sci. Conf. Morogoro, $12^{\text {th }}-14^{\text {th }}$ December 1983.

Pfützner H, Sachse K: Mycoplasma bovis as an agent of mastitis, pneumonia, arthritis and genital disorders in cattle. Rev. sci. tech. Off. int. Epiz. 1996, 15, 1477-1494.

Provost A, Perreau P, Breard A, Le Goff C, Martel JL, Cottew GS: Contagious bovine pleuropneumonia. Rev. sci. tech. Off. int. Epiz. 1987, 6, 625679.

Regalla J, Lefèvre PC: Contagious bovine pleuropneumonia. In: OIE Manual of Standards for Diagnostic Tests and Vaccines. $3^{\text {rd }}$ edition. Office International des Epizooties, Paris, 1996.

Rodríguez JL, Poveda JB, Orós J, Herráez P, Sierra $M A$, Fernández A: High mortality in goats associated with the isolation of a strain of Mycoplasma mycoides subsp. mycoides (Large Colony Type). J. Vet. Med. B. 1995, 42, 587-593.

Ross RF: Mycoplasmas - Animal pathogens. In: Kahane I, Adoni A (eds), Rapid Diagnosis of Mycoplasmas. Plenum Press, New York, 1993.

Rurangirwa FR, McGuire TC, Mbai L, Ndung'u $L$, Wambugu A: Preliminary field test of lyophilised contagious pleuropneumonia vaccine. Res. Vet. Sci. 1991, 50, 240-241.

Rweyemaтu M, Benkirane A: Global impact of infections with organisms of the 'Mycoplasma mycoides cluster' in ruminants. In: Frey J, Sarris K (eds): Mycoplasmas of ruminants: pathogenicity, diagnostics, epidemiology and molecular genetics. COST 826, Report EUR 16934, European Communities, Luxembourg, 1996.

Shimizu T: Isolation of Mycoplasma bovis from calf pneumonia in Japan. Jpn. J. Vet. Sci. 1982, 44, 981-983.

Stalheim OHV: Mycoplasmas of animals. In: Carter GR, Cole JR (eds): Diagnostic Procedures in Veterinary Bacteriology and Mycology. $5^{\text {th }}$ edition.
Academic Press, San Diego, 1990.

Subcommittee on the Taxonomy of Mollicutes: Proposal of minimal standards for description of new species of the class Mollicutes. Int. J. Syst. Bacteriol. 1979, 29, 172-180.

Tanskanen R: The prevalence and level of colonisation by Mycoplasma dispar and other mycoplasmas in calf rearing farms. Acta vet. scand. 1987, 28, 209-226.

Taoudi A, Kirchhoff H, Johnson DW, Choukrallah A: Prevalence of Mycoplasma and Acholeplasma species in cattle exhibiting various clinical diseases and pathological lesions in Morocco. $\mathrm{Zbl}$. Vet. Med. B. 1985, 32, 534-540.

Ter Laak EA, Noordegraaf JH, Dieltjes RPJW: Prevalence of mycoplasmas in the respiratory tracts of pneumonic calves. J. Vet. Med. B. 1992, 39, 553562.

Thiaucourt $F$, and Bölske, G: Contagious caprine pleuropneumonia and other pulmonary mycoplasmoses of sheep and goats. Rev. sci. tech. Off. int. Epiz. 1996, 15, 1397-1414.

Thiaucourt F, Bölske G, Leneguersh B, Smith D, Wesonga $H$ : Diagnosis and control of contagious caprine pleuropneumonia. Rev. sci. tech. Off. int. Epiz. 1996, 15, 1415-1429.

Thomas LH, Gourlay RN, Scott EJ, Howard CJ, Bridger JC: A search for new microorganims in calf pneumonia by the inoculation of gnotobiotic calves. Res. Vet. Sci. 1982, 23, 170-182.

Weisburg WG, Tully JG, Rose DL, Petzel JP, Oyaizu $H$, Yang D, Mandelco L, Sechrest J, Lawrence $T G$, Van Etten J, Maniloff J, Woese CR: A phylogenetic analysis of the mycoplasma: basis for their classification. J. Bacteriol. 1989, 171, 64556467.

Working Group of the FAO/WHO Programme on Comparative Mycoplasmology: The growth inhibition test. World Health Organization Working Document, VPH/MIC/76.7. World Health Organization, Geneva, 1976.

\section{Sammendrag}

Isolation af mykoplasmer fra respirationsvejene hos kvaeg og geder i Tanzania.

En mikrobiologisk undersøgelse af mykoplasmer floraen i respirationsvejene hos kvæg og geder i udvalgte regioner af Tanzania er blevet udført. Ved undersøgelsen af kvæg blev mykoplasmer isoleret fra $60(17,8 \%)$ ud af 338 undersøgte lunger, fra 8 
$(47,1 \%)$ af 17 lymfeknuder, fra $4(13,3 \%)$ af 30 prøver fra pleurahule eksudat og fra $4(3,9 \%)$ af 103 næsehulesvabere. Alle isolater blev identificeret som Mycoplasma mycoides subsp. mycoides, Small Colony type på nær eet isolat identificeret som $\mathrm{Myco}$ plasma arginini hidrørende fra pleurahulen. $M$. mycoides subsp. mycoides, Small Colony type, blev isoleret fra prøver hidrørende fra Dodoma, Iringa, Mbeya, Morogoro og Shinyanga regionerne, hvorfra udbrud af kontagiøs bovin pleuropneumoni er blevet rapporteret. Ved undersøgelsen af geder blev mykoplasmer isoleret fra $54(34,0 \%)$ af 159 undersøgte lunger, fra $41(18,1 \%)$ af 226 næsehulesvabere og fra $4(40,0 \%)$ af 10 prøver pleurahule eksudat. De påviste arter er $M$. capripneumoniae, M. mycoides subsp. mycoides, Small Colony type $M$. ovipneumoniae og $M$. arginini. Isolationen af $M$. capripneumoniae in Coast og Morogoro regionerne bekræfter tilstedeværelsen af kontagiøs caprin pleuropneumoni i regionerne.

(Received February 14, 2000; accepted June 6, 2000).

Reprints may be obtained from: L.J.M. Kusiluka, Department of Veterinary Medicine and Public Health, Sokoine University of Agriculture, P. O. Box 3021, Morogoro, Tanzania. E-mail: kusiluka@suanet.ac.tz, tel: +255232604542 , fax: +255232604647. 